\title{
Editorial: O ALCANCE DO TEXTO POÉTICO
}

A Coordenação do GT Teoria do Texto Poético (ANPOLL) vem prazerosamente anunciar a publicação do volume 7 ( $2^{\circ}$ semestre de 2009) da revista TextoPoético, veículo que divulga os resultados das pesquisas de membros do GT e que tem se afirmado como espaço importante de discussão crítica e teórica da poesia lírica, brasileira e estrangeira.

O ensaio de abertura, "Reflexões sobre a poesia migrante na Itália", da poeta e professora Vera Lúcia de Oliveira (Università di Perugia, Itália), resulta da conferência que a autora, como convidada especial, pronunciou no dia 19 de agosto de 2009, na Faculdade de Ciências e Letras da UNESP/Araraquara, por ocasião do evento "O legado moderno e a (dis)solução contemporânea - I Encontro Nacional do GT Teoria do Texto Poético (ANPOLL)". O estudo aborda o trabalho de poetas e escritores que, vivendo na Itália sob a condição de migrantes ou exilados, adotaram a língua italiana como expressão literária privilegiada. Não é o caso de Vera Lúcia de Oliveira, que, como poeta, expressa-se em português e italiano, conforme pudemos comprovar por meio da leitura emocionada que ela fez de seus poemas, durante o I Encontro.

Os outros sete artigos que compõem o volume foram escritos por membros vinculados ao GT e por professores de pós-graduação e doutorandos de várias universidades brasileiras. O texto de Alexandre Bonafim Felizardo (USP), "O voo entre a vida e o nada: análise do poema 'Elegia (I)' de Orides Fontela", ao cumprir com rigor o que se propõe, também desvenda outros prismas da poesia contemporânea, seja na sua relação com a filosofia, seja na desconstrução que empreende da tradição. O artigo seguinte, "A intertextualidade como engenho: o Brasil de Drummond na Braxília de Nicolas Behr", de Wilberth Salgueiro (UFES), membro do GT, privilegia o estudo das relações intertextuais da poesia do "neomarginal" brasiliense com a de Carlos Drummond de Andrade, com esclarecedores resultados. A poesia brasileira modernista está presente no quarto trabalho, "A máscara da autoria em Mário de Andrade: teatralização da ficção", de Daniela Soares Portela (UNESP/São José do Rio Preto), que, ao lado da análise de alguns dos "Poemas da negra", vale-se da obra ficcional do paulista para evidenciar seus processos de teatralização. 
Os dois textos seguintes privilegiam a poesia portuguesa contemporânea: o de Sandro Ornellas (UFBA), "Moedas da poesia em Gastão Cruz", parte da antologia de Gastão Cruz recentemente lançada no Brasil, A moeda do tempo e outros poemas, para fazer uma oportuna avaliação crítica do importante poeta do grupo Poesia 61. Por sua vez, o artigo de Chimena Barros da Gama (UNESP/Araraquara), membro do GT, estuda com afinco um dos primeiros livros do poeta-crítico Nuno Júdice, A noção de poema.

Os dois textos finais abordam interessantes ressonâncias clássicas no Modernismo internacional, respectivamente o norte-americano e o grego, numa clara demonstração de que a vanguarda não se valeu, apenas, de negações e rupturas radicais em relação ao passado. Assim, o artigo de Sigrid Renaux (UFPR/UNIANDRADE), "Uma releitura da Ars poetica de Archibald MacLeish como reconceptualização de 'Ut pictura poesis", além de traduzir o poema do modernista sucessor de Pound e Eliot (anteriormente vertido para o português, no Brasil, em momentos diferentes, por Péricles Eugênio da Silva Ramos e Marina Rodrigues Bilharinho), faz um estudo comparativo da "Arte poética" de MacLeish com a "Arte poética" de Horácio, evidenciando seus pontos de contato. O último artigo, de Carolina Donega Bernardes (UNESP/São José do Rio Preto), ao debruçar-se sobre o longo poema Odisseia, do grego Nikos Kazantzakis, faz as necessárias conexões com a homônima epopeia de Homero, ressaltando os pontos de interseção e de diferença entre a matriz literária do Ocidente e as novas ideias, inclusive filosóficas, que embasam o poema de Kazantzakis.

Como se vê pelo resumo dos ensaios ora publicados, a TextoPoético mais uma vez cumpre seu papel de fomento à discussão, através da teoria, da crítica e da análise textual, dos problemas universais e atemporais (e, por isso mesmo, ainda candentes para nós, contemporâneos) da poesia lírica brasileira e internacional, num importante alargamento de fronteiras temáticas e de seu corpo de colaboradores.

Tal se coaduna claramente com as três linhas temáticas adotadas pelo GT Teoria do Texto Poético para o biênio 2008-2010: “Os contemporâneos e os fundadores da modernidade lírica" (com abertura também para os fundadores das várias tradições clássicas e neoclássicas que têm nutrido a poesia moderno-contemporânea); "Poesia contemporânea e tradição moderna"; "Teorias modernas e contemporâneas da lírica". 
Queremos agradecer, enfim, aos afiliados do GT e aos membros do Comitê Editorial e do Conselho Editorial da revista pela presteza com que nos auxiliaram na avaliação dos artigos recebidos e na seleção dos que ora se publicam. E estendemos nossos especiais agradecimentos aos colegas da UNESP/Araraquara que, sem participação direta no GT, foram solícitos como pareceristas convidados: Alexandre de Melo Andrade, Fabiane Renata Borsato, João Carlos Biella e María Dolores Aybar Ramírez.

Boa leitura a todos, enquanto aguardamos a colaboração de professores (ligados, necessariamente, a Programas de Pós-Graduação) e de doutorandos interessados em colaborar com os futuros números da revista TextoPoético.

Araraquara, março de 2010

Prof. Dr. Antônio Donizeti Pires Profa. Dra. Solange Fiuza Cardoso Yokozawa Coordenadores do GT 